\title{
医用光イメージング技術
}

\section{光吸収による超音波速度変化を利用した 光断層イメージング*}

단

-

난 항

- -1

다을

\section{堀中博道**}

Optical Tomography Imaging by Use of Ultrasonic Velocity Change Due to Light Absorption / Hiromichi HORINAKA

Key words: optical computed tomography, ultrasonic velocity, laser, living tissue, scattering

\section{1. はじめに}

近年, $\mathrm{X}$ 線の代わりに近赤外光を用いた光 $\mathrm{CT}$ (computed Tomography) が注目されている. 近赤外光 を用いることで，検出物質の波長依存性を利用することが でき, X 線では困難な生体物質の状態の変化や特性の違 いの検出ができると考えられる，例えば，血液中のへモグ ロビンの酸化状態は赤外吸収特性に依存することが知られ ている.また, 最近, がん細胞に選択蓄積する光増感材の 開発も進んでいる.したがって, 検出対象の特性吸収波長 に合った近赤外線をプローブとすることで，生体における 血液中の酸素濃度分布や病変部分の画像化が可能となる.

$\mathrm{X}$ 線 CTでは, 試料に対してX 線を走査して得られた 投影デー夕をもとに, コンピュータによって断層画像を再 構成している. 投影データとは, 線源と検知器を結ぶ直線 路に沿った吸収量である。しかし，X線とは異なり，近 赤外光は生体中で多重散乱するので, 透過光の大部分は直 線路を伝播しておらず，投影デー夕として使用できない． $\mathrm{X}$ 線 CT と同様の方式で断層画像を得るには, 透過光の 中から光源と検知器を結ぶ直線光路近くを伝播する成分 (準直進光) のみを抽出する必要がある. 準直進光成分の 抽出のために透過光のコヒーレンス（位相, 波面, 偏光な ど）を利用した様々な方式が提案され，基礎実験が行われ ている ${ }^{11}$. しかし, 多重散乱のために準直進光成分は極め て微弱であり,さらに㖤折率勾配による偏向と光吸収が区 別できないという問題がある.

最近, 生体の光断層画像を得るために超音波と光の相互

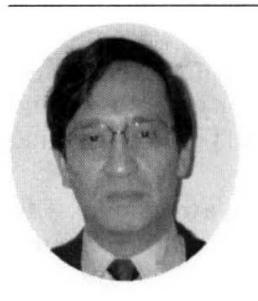

*原稿受付 平成 12 年 12 月 28 日

**大阪府立大学大学院工学研究科(堺市学園町 1-1)

1976 年, 京都工芸瀻維大学大学院工学研究科修 士課程修了, 工学博士, 1997 年, 大阪府立大学 工学部電子物理工学科教授, 現在に至る. 研究 分野: 光物性応用, 半導体スピン工学, 生体医 用光学, 著書: 新しい機能性半導体材料をめざ して (分担執筆) 等
作用を利用する方法が注目されている. 光は生体全体に拡 散するが，超音波は拡散することなく生体中を伝搬するの で, 拡散光を超音波でラベリングすれば局所的な光情報が 得られると考えられる. 医用の超音波エコー装置には, 1 $\mathrm{MHz}$ から $10 \mathrm{MHz}$ の周波数の超音波が用いられている. 超音波を水中に伝播させると位相格子が生じ, 1 10 $\mathrm{MHz}$ の超音波では通常ラマンナス回折が生じる. 光と超 音波の相互作用信号の検出のために, 散乱媒質を透過した 超音波による変調光と参照光とのビート信号を検出する方 式 ${ }^{2)}$ 偏向したビームを検出する方式 ${ }^{3)}$ が試みられてい る. しかし, これらの超音波による光の変調を利用する方 式は, 光が拡散した状態で適用することを期待しているの にかかわらず，相互作用信号の検出に光のコヒーレンスを 用いているところに基本的な問題があり, 測定範囲が限定 される.

光と超音波を用いる生体計測として, さらに, 光音響分 光法も研究されている4).これは, 光短パルスを生体に照 射し, 吸収部分における急激な熱膨張によって発生する超 音波を検出し, 時間遅れから音波が発生した深さを求め, 吸収体の位置情報を得るものである。適用範囲は $10 \mathrm{~mm}$ 以下であり, 経皮吸収や皮下組織の診断装置への応用が期 待されている.

我々は, これらの方式とは異なり, 超音波による生体の 光情報のラベリングの方法として, 光照射による吸収領域 に生じる超音波の速度変化を検出し, 吸収分布を得る方式 （超音波速度イメージング）を考光, 基礎実験を行ってき $た^{5)}$.この方法は信号の検出に光のコヒーレンスを利用し ていないので, 拡散光の状態でも信号強度や空間分解能を 維持できると考えられ, 生体における実用的な光断層測定 法と期待される. 以下に, 検出原理, 実験装置, モデル散 乱媒質を用いた実験の結果などを示す。

\section{2. 超音波速度変化による光情報検出の原理}

光照射による超音波速度変化を利用した光吸収分布測定 の概念図を図 1 (a) に示す. 検出を目的とする物質の特 


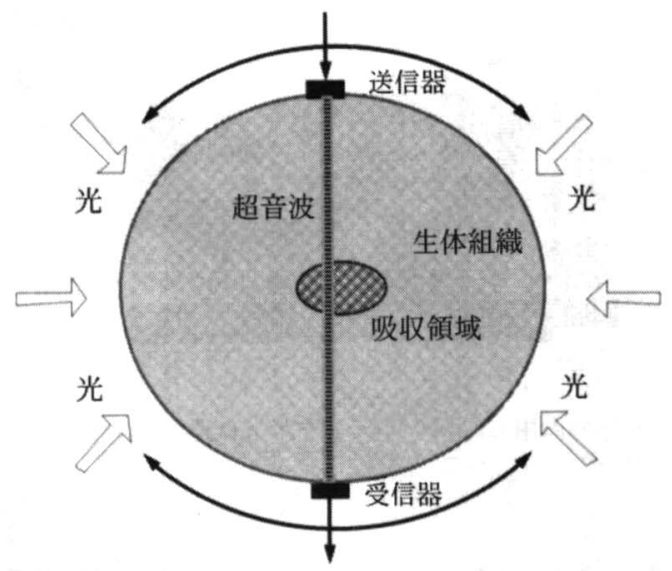

(a)超音波による生体の光吸収情報の検出

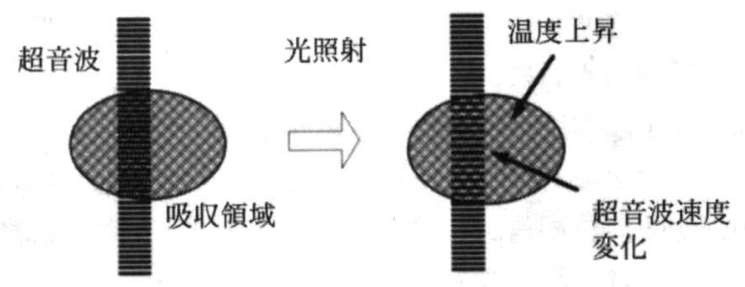

(b) 光吸収領域における超音波速度の変化

図 1 光照射による超音波速度変化を利用した 生体光断層画像の原理

性吸収線に合った波長の光を入射させる. 光は生体中で拡 散するが, 拡散だけを示す領域では温度変化はなく, 吸収 領域でのみ温度が上昇する．超音波の伝播速度は，伝搬媒 質温度によって変化し, 水温が $30^{\circ} \mathrm{C}$ 付近の水中を伝播す る場合には, $1{ }^{\circ} \mathrm{C}$ あたり約 $2 \mathrm{~m} / \mathrm{s}$ 変化することが知られ ている. 図 1 (b) に示すように，超音波が生体内の吸収 領域を伝播したときには，光照射による温度上昇によって 速度変化が生じる，すなわち，超音波の速度変化を測定す ることで，光情報を得ることが可能になる．図1（a）に 示すように超音波を走査することで 2 次元的な情報を得る ことができる.この方法では, 検出されるのは超音波であ り, 散乱はほとんどないので, 画像に有効 な信号の割合が大きく, 空間分解能（超音 波ビームの幅で決まる）もよい.

超音波の速度変化として光学情報の分布 を得るのに 2 つの方式が考えられる.1つ は, 連続波の超音波を, 試料に対して平 行, 回転移動させて, 光照射による速度変 化を投影データとして測定し，CT アルゴ リズムを用いて，吸収分布を得るものであ る.この方法では, CT アルゴリズムを必 要とするが, 組織境界がない場合にも適用 できるという特長をもつ.もう1つは, 超 音波パルスを用いて，組織境界からの反射 パルスの到達時間と光照射による到達時間 の変化を測定することで，位置情報だけて なく，組織内における吸収情報を得ようと

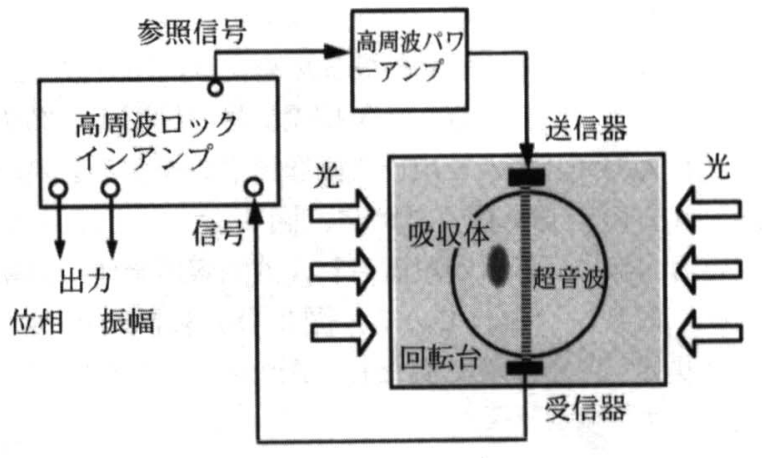

図 2 光断層画像のための光照射による超音波位相変化の測定装置

するものである．この方式を用いれば，従来の超音波工 コー装置に吸収情報を加えることができる．CT アルゴリ ズムを必要としないが，組織境界が存在する場合しか適用 できない.すでに，両方式とも高い散乱媒質中で吸収分布 を得ることに成功しているが，ここでは連続波の超音波を 用いて光照射による位相変化を検出する方式について述べ る.

\section{3. 実 験 装 置}

光吸収による超音波の速度変化を超音波の位相の変化と して検出するために作製した装置の概略を図 2 に, 実際の 装置の試料付近の写真を図 3 に示す.

透明な容器 $(15 \mathrm{~cm} \times 15 \mathrm{~cm} \times 15 \mathrm{~cm})$ の中に, 2 つの超 音波トランスデューサを向き合わせて設置し, それぞれ送 信器, 受信器として用いる. RF ロックインアンプの参照 信号をパワーアンプで増幅させ, トランスデューサ（送信 器）に加え, 超音波 $(5 \mathrm{MHz})$ を発生させる. 光を吸収 した領域では, 温度上昇が起こり, 超音波の速度が変化す る. 受信器出力の位相は伝搬路における音速の変化を敏感 に反映すると考えられ，ロックインアンプを用いて検出す る. 光を照射したときと照射していないときの位相差か ら, 超音波の伝搬路における温度上昇を求め, 光吸収を求

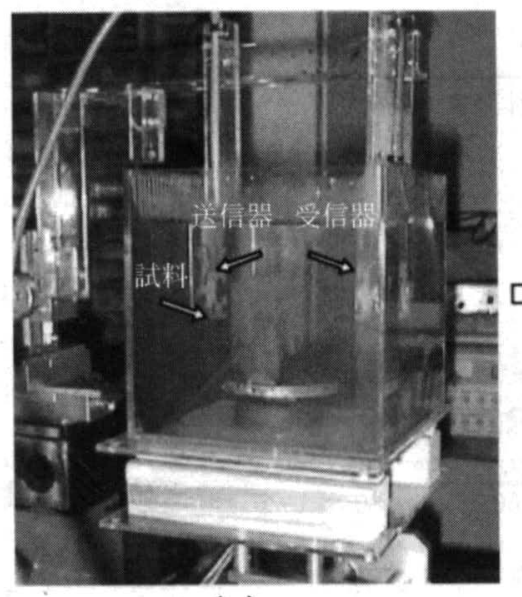

(a)

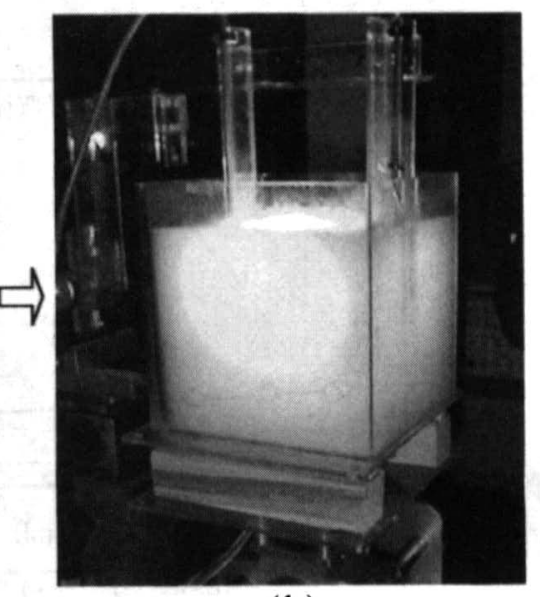

(b)
散乱媒質、Arレーザ照射

図 3 超音波位相変化による光断層画像の測定状況 
める．本方式では，超音波の伝搬路の位相変化の総和が測 定されるので, 2 次元画像を得るためには, 超音波を試料 に対して並進，回転走查し，位相差信号の投影データをも とに CT アルゴリズムを用いて画像再構成をする必要があ る.これらの走査を行うために，図 3 (a) に示すように 透明容器内部に回転台が設置され，透明容器全体が移動ス テージに取り付けられている，図 3 (b) に試料周囲をイ

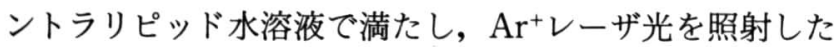
状態を示す。

\section{4. 実験}

生体における水の占める割合は大きく，その超音波に対 する特性は水とほほ同じと考えられる，水中に吸収体とし て黒いスポンジ（厚さ $1 \mathrm{~cm}$ ) を設置し, 上部から $\mathrm{Ar}^{+}$ レーザ光を照射し，スポンジ内部と外部を透過した超音波 の位相シフトを測定した。このとき，スポンジ内部と外部 に薄膜サーミスタを取り付け，超音波が透過した部分の温

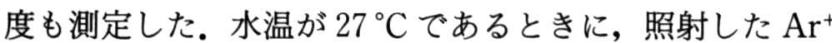
レーザの光強度と超音波の位相シフトの測定結果を図 4 に 示す. ○と $\Delta$ は，それぞれ，黒いスポンジ（厚さ $1 \mathrm{~cm}$ )

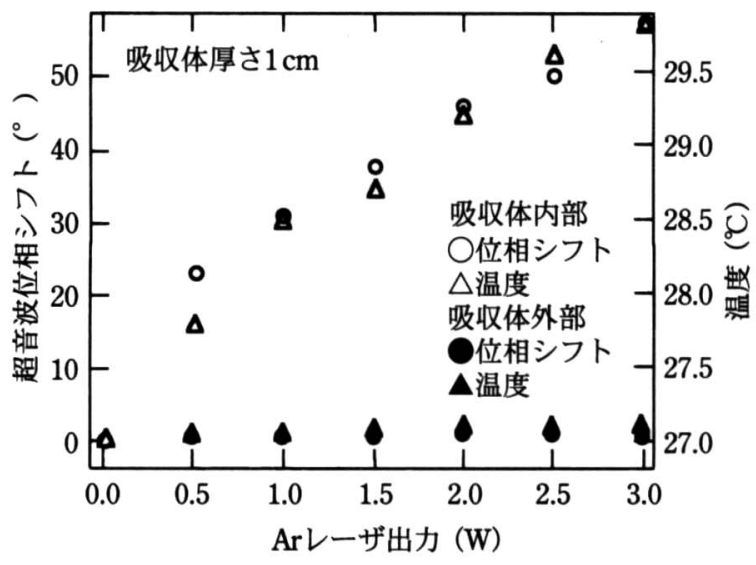

図 4 吸収体（厚さ $1 \mathrm{~cm}$ ）内部における超音波の位相シフトと 温度の励起光強度依存性

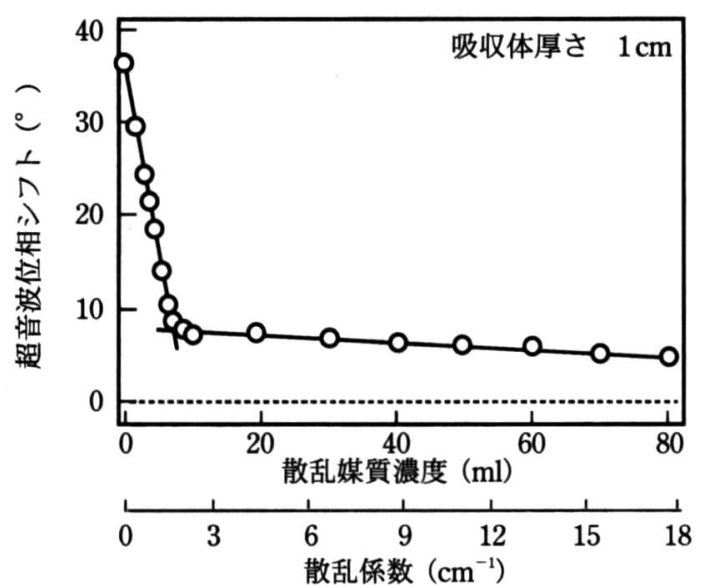

図 5 錯乱媒質（“Intralipid $10 \% ”$ 水溶液）の中での光照射による 超音波位相変化

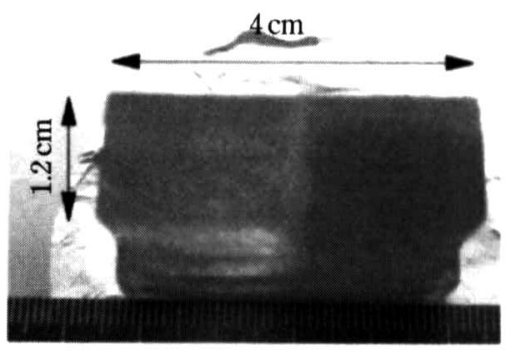

图 6 断層画像用の試料 (寒天で左半分は透明, 右半分は ローダミン $6 \mathrm{G}$ で着色)

内部を伝播した超音波の位相シフトと黒いスポンジ内部の 水温を示す。とムは，それぞれ，スポンジの周囲の水を 伝搬した超音波の位相変化と周囲の水温を示す. 光照射に よって周囲の水温はほとんど変化しなかったが，スポンジ 内部では励起強度に依存して水温が上昇した。 スポンジ内 部の温度変化に対応して超音波の位相差が変化しているこ とが分かる。位相差から求めた速度変化は, 報告されてい る水中における超音波の音速の変化によく一致していた.

次に, イントラリピッド水溶液を散乱媒質として用い, 濃度を変化させて, 吸収体を伝播する超音波の位相を測定 した。散乱媒質水溶液の液面加約 $5 \mathrm{~cm}$ 下の位置に吸収 体として黒いスポンジ（厚さ $1 \mathrm{~cm}$ ）を設置し，上部より $\mathrm{Ar}^{+}$レーザ光 $(2 \mathrm{~W})$ を照射した. 図 5 に測定結果を示 す. 図の破線は光を遮断したときの位相を示し，これを基 準として光を照射したときの位相の測定值を○で示す．等 価散乱係数が $2 \mathrm{~cm}^{-1}$ 以上の濃度では, 光が拡散した状態 であると考えられ, 光照射による超音波の位相変化の濃度 依存性は小さい. 報告されている人の脳の散乱係数（17 $\left.\mathrm{cm}^{-1}\right)^{6)}$ に相当する高い濃度の散乱媒質の中でも, 位相変 化が検出できることが示されている。従来の方式に比べて はるかに高い散乱濃度の媒質においても信号が検出できて いる.

高い散乱係数の媒質中で, 信号が検出できることが分 かったので, 次に断層画像計測の実験を行った. 本方式で は物質の外形ではなく吸収領域が画像化できることを示す ために, 縦 $12 \mathrm{~mm}$, 横 $40 \mathrm{~mm}$, 高さ $20 \mathrm{~mm}$ の透明な寒 天を試料として用い, 半分をローダミン $6 \mathrm{G}$ を用いて着色 した. 試料の寒天の写真を図6に示す. $\mathrm{Ar}^{+}$レーザ光 (515 nm) は, 右半分の着色部分でのみ吸収される.この 試料を, 図 3 (a) に示す透明コンテナの中の回転台の上 に取り付けた。コンテナを等価散乱係数が $17 \mathrm{~cm}^{-1}$ のイン トラリピッド水溶液で満たした。試料を, 超音波に対して 回転, 平行走査し, レーザ照射の有無による超音波の振幅 と位相の変化の測定を行った。

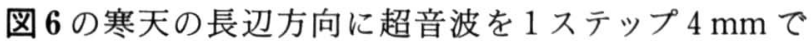
走査したときの, 受信器出力の振幅と位相シフトの測定結 果を図 7 に示す. 図7（a）において，○は光を照射した ときの振幅であり，、は光を照射しないときの振幅であ り，両者にほとんど差は見られない. 図 7 (b) において, 
は光を照射したときの位相で あり，者は光を照射しないとき の位相である.着色された右半 分でのみ違いが見られており， 光吸収が超音波の位相変化とし て検出されていることが分か る。

試料に対する超音波の角度を 変えて, 透過超音波の振幅と位 相を投影データとして測定し た。投影データをもとに断層画 像の構成を試みた。図 8 に投影 データから再構成した断層画像 を示す。図8（a）は超音波の 振幅を投影データとしたときの 画像であり, 図 8 (b) は超音 波の光による位相シフトを投影 データとしたときの画像であ る.それぞれの図の上部には， 振幅，位相シフトの大きさを等 高線で示している。振幅の画像 は寒天の大きさ $(12 \mathrm{~mm} \times 40$ $\mathrm{mm}$ ）に対応した領域が示され ているが，位相シフトの画像は 寒天の吸収領域 $(12 \mathrm{~mm} \times 20$ $\mathrm{mm}$ ) が示されている。これら の結果から，光による位相シフ トの検出によって, 光吸収情報が得られ，光断層画像が構 成できることが示された。

$$
\text { 5. ま と め }
$$

生体における光情報を, 光照射によって吸収領域に生じ る局所的な温度の変化を超音波の速度変化として検出する 方式について提案した，基礎実験を行い，生体の散乱係数 に相当する高い濃度の散乱媒質においても信号検出が可能 であることを示した。さらに，部分的に吸収を示す試料を 用い，透過超音波の光による位相シフトを投影データとし て 2 次元画像を構成し, 吸収部分のみが画像化されること を確認した。

$$
\text { 謝 辞 }
$$

本稿の研究恃，文部省科学研究費補助基盤研究 B (2) (課題番号 12555014）の援助のもとに行われました。研究 を遂行するにあたりご協力いただきました松中敏行様（ア ロカ(株)）に感謝いたします。

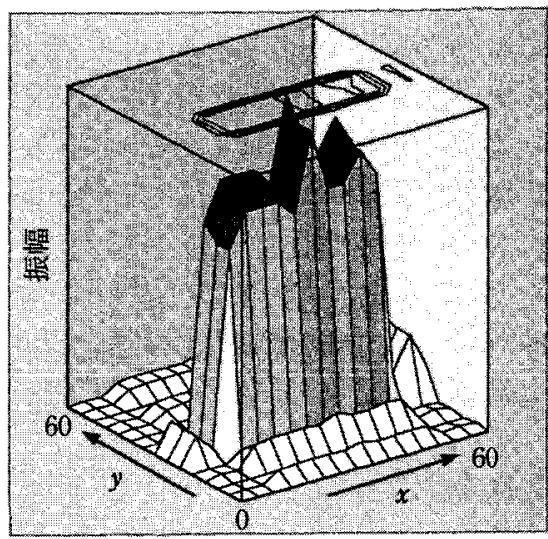

（a）超音波の振幅画像

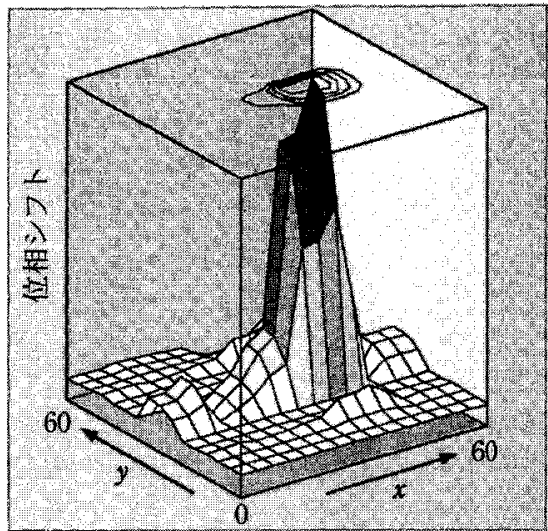

（b）超音波の光による位相变化画像

図 8 超音波の振幅と光による位相 変化を投影データとした画像

\section{参 考 文 献}

1) 光断層画像計測の現状, O PLUS E, 21, 7 (1999)

2) M.Kemple, M.Larionov, D.Zaslavsky and A.Z.Genack: Acoustic-optic tomography with multiply scattered light, J. Opt. Soc. Am., A14, 5, (1997) 1151.

3) L.V.Wang and X.Zhao: Ultrasound-modulated optical tomography of absorbing objects buried in dense tissuesimulating turbid media, Appl. Opt. 36, 28, (1997) 7277.

4）高木隆一著, 沢田嗣郎編：光音響分光法とその応用-PAS, 日 本分光学会測定法シリーズ 1 (学会出版センター, 1997)第 8 章.

5) H. Horinaka, K. Wada, A. Okasaka, Y. Cho, T. Matsunaka, S. Syouhei : Optical computed tomography imaging of absorbers hidden in scattering medium by detection of ultrasonic phase-shift caused by laser illumination-Ultrasonic Velocity Imaging-, Proc. of 2000 IEEE Ultrasonic Symposium (Puerto Rico, 2000), (in press).

6) D.S.Smith, W.J.Levy, S.Carter, M.Haida and B.Chance: Proc. Photon Migration and Imaging in Random Media and Tissures, (SPIE, Bellingham, Wash., 1993) 511. 